Conference Paper

\title{
Machine Effective Analysis Using OEE and Six Big Losses Methods in the Filter Making Factory
}

\author{
Muhammad Haris Indra Avichena, Endang Pudji W.* \\ Department of Industrial Engineering, Engineering Faculty, Universitas Pembangunan Nasional "Veteran" \\ Surabaya, East Java, Indonesia
}

*Corresponding author:

E-mail: endangpudjiti@gmail.com

\begin{abstract}
Improper machine maintenance and handling can cause a decrease in the level of engine performance which results in reduced engine effectiveness and productivity. Filter making company is a company engaged in manufacturing filters. The problem faced by the filter manufacturing company is that the company has a breakdown time on the production machine that is too high which causes the machine performance to decrease. To increase productivity, Total Productive Maintenance (TPM) measurements are calculated using Overal Equipment Effectiveness (OEE) calculations. OEE is a systematic method for measuring the effectiveness of a machine or equipment process. In general, the size of the OEE is influenced by the dominant factor that causes the low performance of a machine or equipment which is commonly called six big losses. After that, get the cause of the problem that occurs by using a causal diagram. The results showed that the OEE value on the production machine was $40.63 \%$, the effectiveness value was classified as low because the OEE value standard for world-class companies was $85 \%$. The biggest factor influencing the low value of OEE on this production machine is performance efficiency with the largest percentage of six big losses found in reduced speed losses and idling and minor stoppages losses with an average percentage of $59.41 \%$ and $48.86 \%$ of all losses. The thing done to overcome the low OEE value on the production machine is the implementation of autonomous maintenance that is given to each operator, conduct training for operators and maintenance technicians, supervise operators about work hygiene.
\end{abstract}

Keywords: Production machines, filter making companies, total productive maintenance, overall equipment effectiveness, six big losses, cause and effect diagram

\section{Introduction}

The company is engaged in the production of filters, its products are distributed to most of Indonesia. The resulting product consists of various kinds of filters according to the company it serves. The company operates 5 types of filter manufacturing machines. Based on the results of interviews, the highest damage often occurs in a lathe compared to other machines. Focusing on the output produced, its operational activities are inseparable from problems related to engine effectiveness. Lathes used to produce filters cannot be left without maintenance and continuous maintenance of their production machines.

The company is engaged in the production of filters, its products are distributed to most of Indonesia. The resulting product consists of various kinds of filters according to the company it serves. The company operates 5 types of filter manufacturing machines. Based on the results of interviews, the highest damage often occurs in a lathe compared to other machines. Focusing on the output produced, its operational activities are inseparable from problems related to engine effectiveness. Lathes used to produce filters cannot be left without maintenance and continuous

\section{How to cite:}

Avichena, M. H. I., \& Pudji W., E. (2020). Machine effective analysis using OEE and six big losses methods in the filter

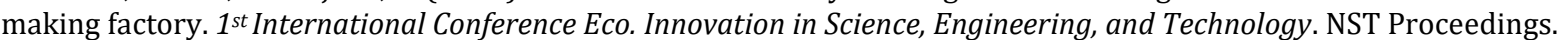
pages 280-287. doi: 10.11594/ nstp.2020.0544 
maintenance of their production machines. The machine will experience a decrease in performance and if left unceasing, will suffer damage which will ultimately result in loss of operating time. The main purpose of engine maintenance at each company is to achieve a zero level defect and zero breakdowns. In practice, the improvement effort that is carried out is often a waste of the company, because it does not touch the real root of the problem. It is because there are not problems and factors that cause a decrease in engine performance.

Based on the problems above, a research was conducted aimed at increasing the effectiveness of the lathe in the filter manufacturing plant. The proposed method is Total Productive Maintenance (TPM) with the calculation of Overall Equipment Effectiveness (OEE) and Six Big Losses. TPM does not only focus on how to optimize the effectiveness of equipment or materials supporting work activities, but also pay attention to how to increase the effectiveness of workers or operators who will later take control of the equipment and materials. OEE is defined as a measure to evaluate the effectiveness of the equipment that seeks to identify production losses. Six Big Losses serves to find out what factors cause a decrease in engine efficiency

\section{Literary Review \\ Total Productive Maintenance (TPM)}

According to Nakajima (1988), TPM is a maintenance concept that involves all workers who aim to achieve effectiveness in the entire production system through participation and maintenance activities that are productive, proactive, and planned. a method that aims to maximize the efficiency of the equipment use, and establish a preventive maintenance system that is designed for the entire equipment by implementing a rule and provide motivation to all parts within a company, through increasing componentization of all members who involved from top management to the lowest level.

\section{Overall Equipment Effectiveness (OEE)}

Ansori (2014), Overall Equipment Effectiveness (OEE) is a metric that focuses on how effectively a production operation is carried out. Every company wants their equipment to work optimally, no time is wasted, but in reality, it is not easy. For this reason, measurement of OEE is very necessary, the OEE standard value according to the Japan Institute of Plant Maintenance (JPIM) is $85 \%$. This formula can be used to calculate OEE:

OEE=Availability $x$ Perfomance Efficiency $x$ Rate of Quality Product

1. Availability

2. Performance Efficiency

$$
\text { Availability }=\frac{\text { Loading time }- \text { downtime }}{\text { Loading time }} \times 100 \%
$$

Perfomance Efficiency= Processed amount $x$ ideal cycle time

$$
\text { Operation time } \quad x 100 \%
$$

3. Rate of quality product

Rate of quality product = amount produced - amount reject

$$
\text { Amount produced } \quad x 100 \%
$$

4. Six Big Losses

According to Kurniawan (2013), the production process certainly has losses that affect its success, the losses by Nakajima are grouped into the big 6 , those are: 
a. Equipment Failure Losses

Equipment failure losses $=\underline{\text { downtime }}$

Loading time $\quad x 100 \%$

b. Setup and Adjustment Losses

$$
\begin{gathered}
\text { Set up adjustment losses } \\
\text { Loading time } \\
\text { Lodime } \\
\times 100 \%
\end{gathered}
$$

c. Idling and Minor Stoppages Losses

Dling and minor stopages losses $=\underline{n o n}$ productive time

d. Reduce Speed Losses

$$
\text { Loading time } \quad x 100 \%
$$

Reduced speed losses $=$ operation time - (ideal cycletime $x$ total prodution $)$

Loading time

$x 100 \%$

e. Defect losses:

Defect losses: ideal cycle time x total product defect

$$
\text { Loading time }
$$

$x 100 \%$

f. Yield/Scrap Losses:

$$
\text { Scrap losses }=\frac{\text { ideal cycle time } x \text { scrap }}{\text { Loading time }} \times 100 \%
$$

\section{Pareto Diagram}

According to Budi (2016), Pareto Diagrams are tools that arrange items sequentially based on the magnitude of their contribution, so they can identify by deploying several items on items that have maximum effect.

\section{Causal Diagram}

According to Mukhri (2014), a causal diagram is to identify various possible causes of a problem. This diagram is used to illustrate the identification of the root cause of an outcome. This diagram can be used to design phases of the production process aimed to identify the root causes of problems

\section{Results Method}

Explanation of the problem steps:

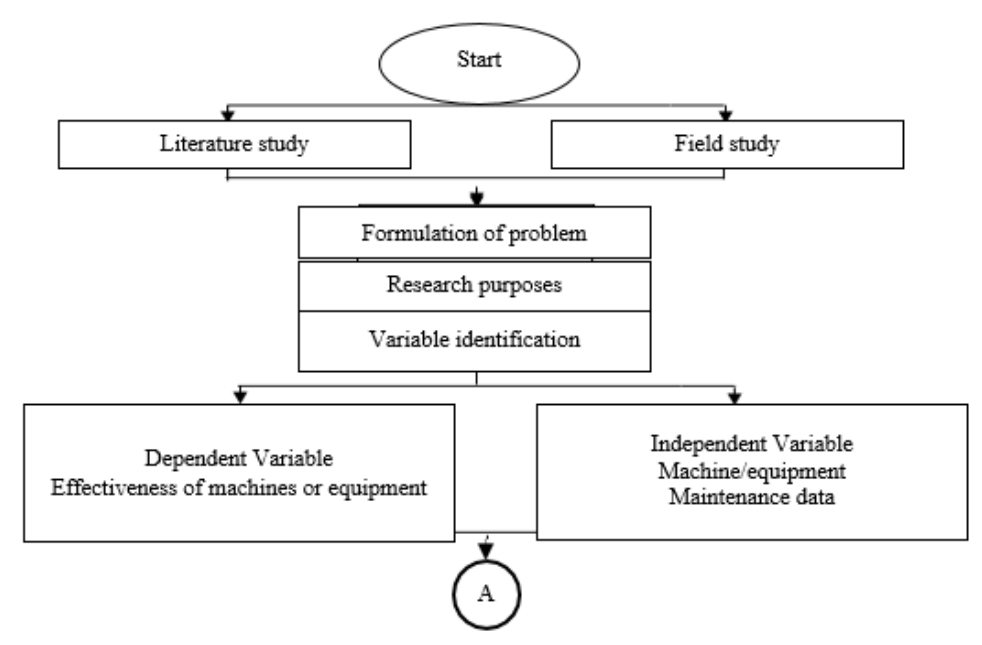




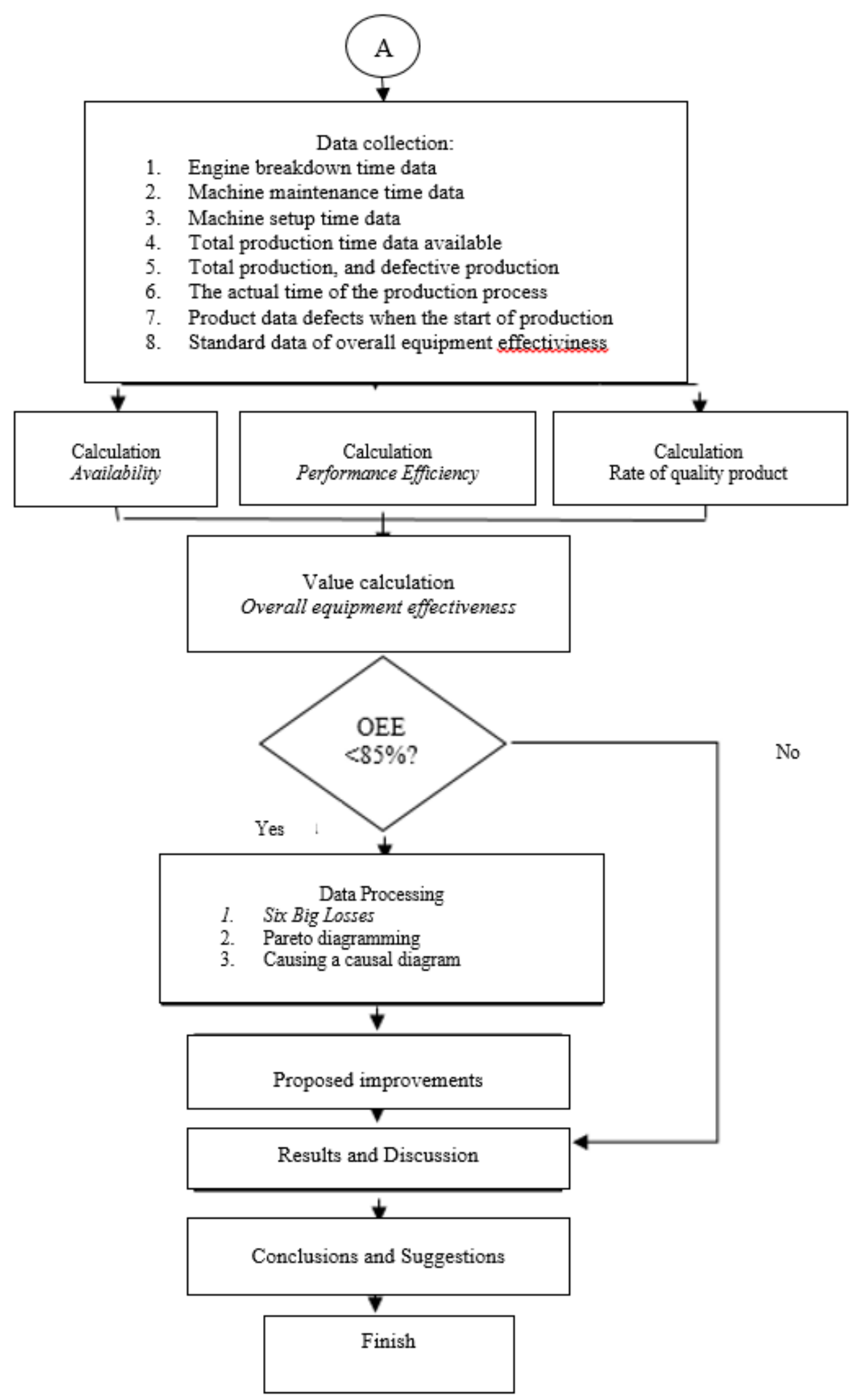




\section{Results and Discussion}

\section{Overall equipment effectiveness calculation}

The summary of the OEE value calculations result can be seen in table 1.

Tabel 1. Overall Equipment Effectiveness (OEE) value in production Line 3 January until desember 2018 pe-

\begin{tabular}{|c|c|c|c|c|}
\hline Month & $\begin{array}{c}\text { Availability } \\
\text { (\%) }\end{array}$ & $\begin{array}{c}\text { Performance } \\
\text { Efficiency } \\
(\%)\end{array}$ & $\begin{array}{c}\text { Rate of Quality } \\
\text { Product } \\
(\%)\end{array}$ & $\begin{array}{l}O E E \\
(\%)\end{array}$ \\
\hline January & 95.54 & 88.43 & 93.29 & 78.81 \\
\hline Febuary & 93.73 & 86 & 93.34 & 75.23 \\
\hline March & 97.24 & 29.91 & 93.88 & 27.3 \\
\hline April & 97.99 & 31.74 & 93.41 & 29.05 \\
\hline May & 97.46 & 45.15 & 93.01 & 40.92 \\
\hline June & 95.11 & 77.29 & 93.1 & 68.43 \\
\hline July & 98.19 & 29.3 & 91.97 & 26.45 \\
\hline August & 98.86 & 29.14 & 92.39 & 26.61 \\
\hline September & 98.43 & 31.56 & 91.73 & 28.49 \\
\hline October & 98.66 & 32.6 & 92.87 & 29.86 \\
\hline November & 94.78 & 34.68 & 92.03 & 30.24 \\
\hline December & 94.39 & 31.19 & 88.9 & 26.17 \\
\hline
\end{tabular}

\section{Six big losses calculation}

Summary of calculations for six big losses:

Table 2. Summary from every Losses calculation in each month

\begin{tabular}{ccccccc}
\hline Month & $\begin{array}{c}\text { Equipmen } \\
\text { t Failure } \\
\text { Losses }\end{array}$ & $\begin{array}{c}\text { Set Up And } \\
\text { Adjustment } \\
\text { Losses }\end{array}$ & $\begin{array}{l}\text { Idling And } \\
\text { Minor } \\
\text { Stoppages } \\
\text { Losses }\end{array}$ & $\begin{array}{l}\text { Reduced } \\
\text { Speed } \\
\text { Losses }\end{array}$ & $\begin{array}{l}\text { Defec } \\
\text { t }\end{array}$ & $\begin{array}{c}\text { Yield/ } \\
\text { Lcrap }\end{array}$ \\
\hline January & 1.06 & 0.26 & 7.89 & 29.59 & 5.66 & Losses \\
Febuary & 2.43 & 0.6 & 6.44 & 31.53 & 5.36 & 2.19 \\
March & 1.51 & 0.17 & 64.96 & 73.81 & 1.78 & 0.60 \\
April & 0.77 & 0.14 & 65.47 & 67.43 & 2.04 & 0.85 \\
May & 0.82 & 0.25 & 46.97 & 53.20 & 3.07 & 1.37 \\
June & 1.64 & 0.23 & 18.68 & 36.18 & 5.07 & 1.97 \\
July & 0.74 & 0.08 & 69.14 & 69.13 & 2.31 & 1.05 \\
August & 0.16 & 0.16 & 66.01 & 64.79 & 2.19 & 0.93 \\
September & 0.50 & 0.12 & 63.18 & 92.33 & 2.56 & 1.21 \\
October & 0.25 & 0.14 & 55.6 & 60.87 & 2.29 & 1.12 \\
November & 4.18 & 0.11 & 60.97 & 67.23 & 2.61 & 1.18 \\
December & 4.50 & 0.17 & 61.06 & 66.84 & 3.26 & 1.57 \\
\hline
\end{tabular}




\section{Pareto diagram making}

The following sorting the average percentage value of each loss can be seen in table 3 , after that a Pareto diagram is made in Figure 2 below:

\begin{tabular}{clll}
\multicolumn{4}{l}{ Table 3. Average percentage value sorting from the highest to the lowest in each Losses } \\
\hline Losses Type & Average & Percentage & $\begin{array}{l}\text { Percentage cumula- } \\
\text { tive }\end{array}$ \\
\hline Reduced Speed Losses & 59.41 & 51.89 & 51.89 \\
Idling And Minor Stoppages Losses & 48.86 & 42.67 & 94.56 \\
Defect Losses & 3.18 & 2.77 & 97.33 \\
Equipment Failure Losses & 1.54 & 1.34 & 98.67 \\
$\quad$ Yield/Scrap Losses & 1.3 & 1.13 & 99.8 \\
Set Up And Adjustment Losses & 0.2 & 0.17 & 100 \\
$\quad$ Total & 114.49 & 100 & \\
\hline
\end{tabular}

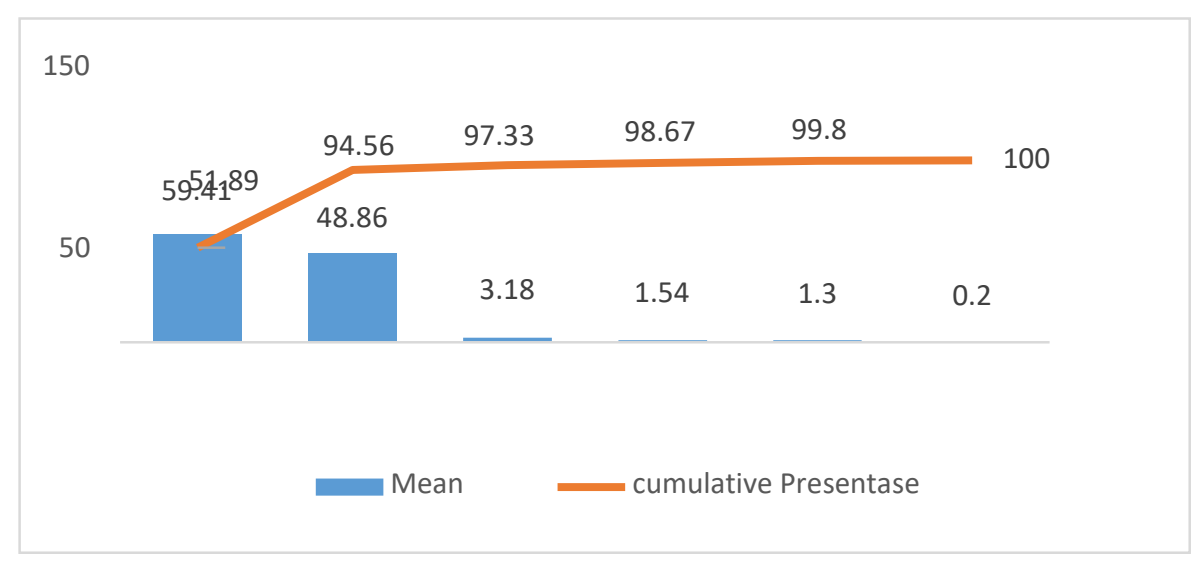

Figure 2. Pareto Diagram each Loss

\section{Causal diagram making}

Based on the results of interviews from the maintenance, production, and waste so, it can be made a program of cause and effect and the following picture from the causal diagram of the causes of Reduced Speed Losses:

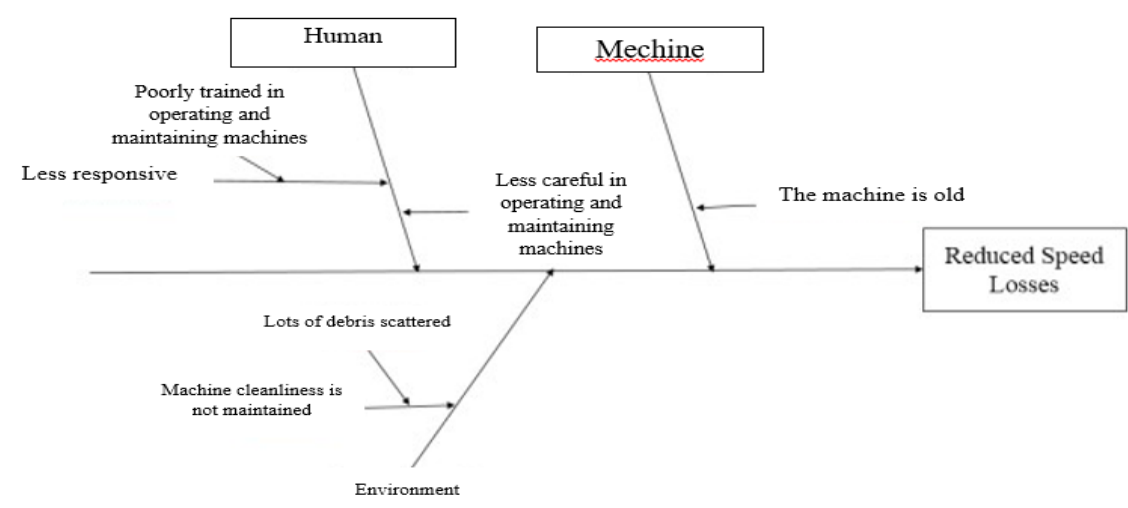

Figure 3. Causal diagramreduced speed loss 


\section{Result analysis \\ OEE analysis}

From table 1 above, the average value of OEE that occurs in production machines is $40.63 \%$. OEE value standard that can be used as a long-term goal is $85 \%$ so that all existing values have values below the average OEE standard. Based on JIPM, it does not fulfill the $85 \%$ standard so the product is considered to have a low score and needs improvement as soon as possible.

\section{Six big losses analysis}

From the Pareto diagram in Figure 1, it can be seen that the largest value of losses in production machines in making filters factory in 2019 is Reduced Speed Losses: that is $59,412 \%$, due to the low productivity of the machine which is caused by stopping repeatedly or the machine operates without producing products.

\section{Causal diagram analysis}

From the causal diagram 3 above, it can be seen the cause of the losses, then a causal diagram analysis is made in table 6 as follows:

Table 6. Causal diagram analysis

\begin{tabular}{|c|c|c|c|c|}
\hline No & Causal root & Causal factor & The effect & Proposed settlement \\
\hline \multirow{4}{*}{1} & $\begin{array}{l}\text { Inaccurate due to } \\
\text { haste }\end{array}$ & Human & \multirow{4}{*}{$\begin{array}{l}\text { Reduced } \\
\text { speed losses }\end{array}$} & $\begin{array}{l}\text { Supervision of the operator is further } \\
\text { enhanced }\end{array}$ \\
\hline & $\begin{array}{l}\text { Less responsive } \\
\text { because it is less } \\
\text { trained }\end{array}$ & & & $\begin{array}{l}\text { Supervision of the operator is further } \\
\text { enhanced }\end{array}$ \\
\hline & $\begin{array}{l}\text { The age of the } \\
\text { engine is old }\end{array}$ & Machine & & $\begin{array}{l}\text { Replacement of machines or equipment } \\
\text { must be on schedule }\end{array}$ \\
\hline & $\begin{array}{l}\text { Lack of Engine } \\
\text { cleanliness }\end{array}$ & Environment & & $\begin{array}{l}\text { Clean the machine and work area } \\
\text { before or after the production process }\end{array}$ \\
\hline
\end{tabular}

\section{Proposed recommendation}

Recommendations on how to improve machine effectiveness and machine productivity on production machines in a filter manufacturing company using fishbone diagrams is to use an autonomous maintenance method so that the mindset of operators who think that operators only use the equipment and others who will fix it then it can be changed so that machine and equipment maintenance in this company can run well and damage can be prevented.

\section{Conclusion}

Based on the results of the application of total productive maintenance analysis calculation on production machines in the filter manufacturing company can be known are as follows:

1. The effectiveness value of the machine in the production machine is as follows: an average availability value of $96.70 \%, 45.58 \%$ performance efficiency, and a $92.49 \%$ rate of product quality. The average of OEE value calculation result is $40.63 \%$. The result of the six big losses calculation that caused the low OEE value was Reduced Speed Losses, which was the biggest damage from the overall damage that occurred with the result, which was $59.41 \%$.

2. ecommendations on how to improve machine effectiveness and machine productivity 
on production machines in making filters factory using fishbone diagrams is to use autonomous maintenance methods so that the mindset of operators who think that operators only use the equipment and others who will fix it then it can be changed so that machine maintenance and equipment in this company can run well and damage can be prevented.

\section{References}

Ansori, Nachnul dan M. Imron Mustajib. 2013. Sistem Perawatan Terpadu (Integrated Maintenance System). Yogyakarta: Graha Ilmu. Kho, B. 1 November 2016. Ilmu Manajemen Industri. Dilihat pada tanggal 11 Febuari 2019, dari QC Seven Tools (7 Alat Pengendalian Kualitas): http://ilmumanajemenindustri.com /qc-seven-tools-tujuh-alatpengendalian-kualitas/

Kurniawan, Fajar. 2013. Manajemen Perawatan Industri. Yogyakarta: Graha Ilmu.

Mukhril. 2014. Total Productive Maintenance and Total Quality Management. Tangerang: Megakarya.

Nakajima, S. 1988. Introduction to TPM (Total Productive maintenance). Productivity Press, Cambridge, MA.

Vorne Industries Inc. 2002. Standar Nilai OEE Kelas Dunia. Dilihat pada tanggal 11 Febuari 2019, dari World-Class OEE: https://www.oee.com/world-class-oee.html 